\title{
Glucocorticoids Differentially Increase Nerve Growth Factor and Basic Fibroblast Growth Factor Expression in the Rat Brain
}

\author{
Italo Mocchetti, ${ }^{1}$ Giulio Spiga, ${ }^{1}$ Valerie Y. Hayes, ${ }^{2}$ Paul J. Isackson, ${ }^{3}$ and Annamaria Colangelo ${ }^{1}$ \\ ${ }^{1}$ Department of Cell Biology, Division of Neurobiology, Georgetown University, School of Medicine, Washington, DC \\ 20007, and ${ }^{2}$ Mayo Clinic Molecular Neuroscience Doctoral Program and ${ }^{3}$ Department of Biochemistry and Molecular \\ Biology, Mayo Clinic, Jacksonville, Florida 32224
}

\begin{abstract}
Adrenocorticotropin hormone (ACTH) and adrenal steroids may influence trophic processes operative in neuronal plasticity. Because nerve growth factor (NGF) and basic fibroblast growth factor (bFGF) participate in neuronal trophism, we have investigated whether adrenal steroids induce the expression of these two trophic factors in the rat brain. The systemic administration of dexamethasone (DEX) elicited a rapid (within $3 \mathrm{hr}$ ) and sustained accumulation of bFGF and NGF mRNA in the cerebral cortex and hippocampus. Regional studies showed that DEX increases bFGF but not NGF mRNA in the cerebellum, striatum, and hypothalamus. In situ hybridization studies revealed that DEX increases NGF mRNA in superficial layers of the cerebral cortex and in the dentate gyrus of the hippocampus, and bFGF
\end{abstract}

mRNA throughout the brain, suggesting that DEX induces NGF mRNA in neurons and bFGF in glial cells. ACTH administered systemically elicited a temporal and regional induction in NGF and bFGF mRNA similar to that obtained with DEX. Increases in NGF and bFGF mRNAs were also observed after administration of corticosterone and, albeit to a lesser extent, aldosterone, suggesting that the pituitary-adrenocortical axis plays an important role in the regulation of NGF and bFGF expression in the brain. Our data suggest that NGF and bFGF represent a link by which the adrenal cortical system can exert trophic action on the CNS.

Key words: NGF; bFGF; dexamethasone; ACTH; corticosterone; aldosterone; cerebral cortex; hippocampus
The nervous and endocrine systems are engaged in an intense biological dialogue and, by sharing many chemical signals, interact at several levels to shield the organism against noxious agents or hostile environmental conditions. The role of adrenal steroids in the neuroendocrine regulation of hypothalamic-pituitary-adrenocortical system in response to stress is well documented. The brain expresses both mineralocorticoid and glucocorticoid receptors and is, among other tissues, a target for adrenal corticosteroids (McEwen et al., 1986). Indeed, adrenal secreted steroids appear to regulate memory consolidation and learning, and influence mood and complex behavioral interactions (McEwen et al., 1986). A great deal of research has focused on the hypothesis that adrenal steroids or adrenocorticotropic hormone (ACTH) might be important regulators of trophic processes operative in synaptic plasticity. During development, glucocorticoids modulate cell growth and differentiation and inhibit cell proliferation (Meyer, 1985), and ACTH increases nerve terminal branching (Strand et al., 1989), typical responses that are belicved to be associated with synaptic plasticity. In the mature brain, corticosterone reduces both cell death of hippocampal granule cells (Sloviter et al., 1989) and morphological changes of the dentate gyrus (Gould et al., 1990) after adrenalectomy. Thus, it appears that some populations

Received Aug. 7, 1995; revised Dec. 19, 1995 ; accepted Jan. 2, 1996.

This work was supported by a Research Career Development Award NS01675 and National Institutes of Health Grant NS29664 to I.M. We thank Drs. A. Baird, S. Goodrich, and S. Whittemore for the generous gift of the plasmids, Dr. W. Herblin for the gift of bFGF antibody. We also thank Dr. P. Follesa and S. J. Rabin for invaluable help in some of the experiments.

Correspondence should be addressed to Dr. Italo Mocchetti, Department of Cell Biology, Georgctown University, School of Medicine, 3900 Reservoir Road NW, Washington, DC 20007

Copyright $(1996$ Socicty for Neuroscience $\quad 0270-6474 / 96 / 162141-(18 \$ 05.00 / 0$ of neurons require a continuous influx of adrenal steroids to maintain structural integrity and enhance survival.

Many of the primary effects of adrenal steroids involve transcriptional regulation of a subset of genes in specific cell types, including neurotransmitters, receptors, and neuropeptides (Harlan, 1988). However, little is known about the mechanisms of these effects and the basis for a "neurotrophic" activity of the adrenal corticosteroids. Given the well established role of neurotrophic factors and the complexity of molecular events influencing synaptic plasticity, it has been suggested that adrenal steroids may exert trophic activity by inducing the synthesis and availability of trophic factors in the developing as well as mature CNS (Aloe, 1989; Mocchetti, 1991). Indeed, several lines of independent evidence have demonstrated that the synthetic glucocorticoid dexamethasone (DEX) modulates the expression of nerve growth factor (NGF) in selected brain regions (Fabrazzo et al., 1991; Barbany and Persson, 1992; Saporito et al., 1994), suggesting that the induction of trophic factor synthesis represents a link by which the adrenal cortical system can exert trophic action in the mature CNS.

Relatively little is known about the contribution of adrenal corticosteroids and the pituitary ACTH in the induction of NGF. Moreover, it is still unclear what role the hypothalamic pituitaryadrenal axis has in the regulation of basic fibroblast growth factor (bFGF), a prototype member of the heparin trophic factor family (Burgess and Maciag, 1989), which is believed to play a role in CNS plasticity (Anderson et al., 1988; Otto and Unsicker, 1990; Follesa et al., 1994). We report that synthetic and naturally occurring adrenal steroids induce a temporal and anatomical induction of bFGF expression distinct from that of NGF.

\section{MATERIALS AND METHODS}

Animal treatment. Adult male and female Sprague-Dawley rats (200-250 gm; Harlan Spraguc-Dawley, Indianapolis, IN) were housed in a 
temperature-controlled environment with $12 \mathrm{hr}$ light/dark cycle and access to food and water ad libitum. Animals received a single dose of vehicle (ethanol-saline 1:9) used to dissolve hormones, DEX, aldosterone, corticosterone (Sigma, St. Louis, MO), or ACTH (Rhone-Poulenc Rorer, Collegeville, PA) subcutaneously. Rats were killed by decapitation at various times after the injection. Adrenalectomized and shamoperated rats were from Harlan. Adrenalectomized rats received saline in place of drinking water. Animals used for in situ hybridization were killed $3 \mathrm{hr}$ after treatment by injection with a lethal dose of sodium pentobarbital $(50 \mathrm{mg} / \mathrm{kg})$ and intracardially perfused with $4 \%$ paraformaldehyde in $0.1 \mathrm{M}$ phosphate buffer (PBS), $\mathrm{pH} 7.4$. After perfusion the brains were removed, post-fixed in $4 \%$ paraformaldehyde at $4^{\circ} \mathrm{C}$ for $1-2 \mathrm{~d}$ and then transferred to $20 \%$ sucrose $/ 4 \%$ paraformaldehyde for $1-2 \mathrm{~d}$. Rats used for biochemical determination were killed by decapitation, the brain areas quickly dissected on ice (Glowinski and Iversen, 1966), frozen on dry ice, and stored at $-70^{\circ} \mathrm{C}$ until processed.

RNase protection assay. RNase protection assay and preparation of cRNA probes were performed as described previously (Follesa and Mocchetti, 1993; Follesa et al., 1994). The 830 base ${ }^{32}$ P-labeled NGF RNA probe, which contains a 771 base portion of the rat NGF cDNA and 59 bases of the Bluescript polylinker Iegion, was generated with T3 RNA polymerase from EcoRI linearized pBSrNGF (Whittemore et al., 1988) (a gift from Dr. S. Whittemore, University of Miami, Miami, FL). The plasmid RUbFGFIO3 (a gift from Dr. A. Baird, The Whittier Institute, La Jolla, CA), containing a 1016 basc portion of the rat bFGF cDNA (Shimasaki et al., 1988), was linearized with NooI to use as a template for the in vitro transcription assay with T7 RNA polymerase. This procedure generated a ${ }^{32} \mathrm{P}$-labeled 524 base probe, which includes the 477 bases of hFGF cRNA and 47 bases of the plasmid polylinker region (Follesa and Mocchetti, 1993; Follesa et al., 1994). The cRNA for acidic FGF (aFGF) was generated from HBGF-I plasmid (Goodrich et al., 1989) (a gift from Dr. S. Goodrich, Alton Jones Cell Scicnce, Lake Placid, NY) as described previously (Follesa et al., 1994). The cRNA for cyclophilin was in vitro transcribed with SP6 polymerase from EcoRI linearized plasmid p1G15 (Colangelo et al., 1994; Follesa et al., 1994; Hayes et al., 1995). This probe was used as a standard control to monitor artifacts attributable to extraction of RNA.

RNA was extracted from brain tissues (Chomczynski and Sacchi, 1987). Total RNA $(20-25 \mu \mathrm{g})$ was dissolved in $20 \mu \mathrm{l}$ of hybridization solution containing $150,000 \mathrm{cpm}$ of a ${ }^{32} \mathrm{P}$-labeled bFGF, and NGF cRNA probe (specific activity $>6 \times 10^{8} \mathrm{cpm} / \mu \mathrm{g}$ of RNA each). To balance the relatively high abundance of cyclophilin RNA, p1G15 was labeled to a lower specific activity $\left(\sim 1 \times 10^{6} \mathrm{cpm} / \mu \mathrm{g}\right.$ of $\left.\mathrm{RN} \Lambda\right)$. Hybridization was performed at $50^{\circ} \mathrm{C}$ overnight. RNA was digested with RNase $A(1 \mathrm{U} / \mathrm{ml})$ and $\mathrm{T} 1(200 \mathrm{U} / \mathrm{ml})$ for $30 \mathrm{~min}$ at $37^{\circ} \mathrm{C}$. The reaction was stopped by extracting the sample with a solution $(1: 1 \mathrm{v} / \mathrm{v})$ containing $4 \mathrm{M}$ guanidine isothiocyanate, $25 \mathrm{~mm}$ sodium citrate, $0.5 \mathrm{M}$ sarkosyl, and $0.1 \mathrm{M}$ 2-mercaptoethanol, and samples were precipitated with isopropanol (1:1 $\mathrm{v} / \mathrm{v}$ ). The pellet containing the RNA:RNA hybrid was dissolved in loading buffer ( $80 \%$ formamide, $0.1 \%$ xylene cyanol, $0.1 \%$ bromophenol blue, 2 mM EDTA), boiled at $95^{\circ} \mathrm{C}$, and separated on a $5 \%$ polyacrylamide/urea sequencing gel. The gel was dried and the bFGF and NGF mRNA protected fragments were visualized by autoradiography on x-ray film using an intensifying screen (Hyperscreen, Amersham, Arlington Heights, IL). The content of trophic factor mRNA was calculated by measuring the peak densitometry area of the autoradiograph analyzcd with a Hoefer GS 300 scanning densitometer (Hocfer, San Francisco, CA) normalized by the peak densitometry area of the cyclophilin autoradiograph band as described previously (Follesa and Mocchetti, 1993; Follesa et al., 1994).

In situ hybridization. In situ hybridization was performed as described previously (Gall and Isackson, 1989; Isackson et al., 1991; Hayes et al., 1995). In brief, $25 \mu \mathrm{m}$ coronal sections were generated on a freczing microtome, transferred sequentially through $0.1 \mathrm{M}$ glycine in PBS, proteinase $\mathrm{K}(1 \mu \mathrm{g} / \mathrm{ml})$ in $0.1 \mathrm{M}$ Tris buffer, $\mathrm{pH} 8.0 / 50 \mathrm{~mm}$ FDTA for $30 \mathrm{~min}$ at $37^{\circ} \mathrm{C}, 0.25 \%$ acetic anhydride in $0.1 \mathrm{M}$ triethanolamine for $10 \mathrm{~min}, 2 \times$ SSC for $30 \mathrm{~min}$ and then incubated for $1 \mathrm{hr}$ at $60^{\circ} \mathrm{C}$ in hybridization buffer containing $50 \%$ formamide, $10 \%$ dextran sulfate, $0.7 \%$ ficoll, $0.7 \%$ polyvinyl pyrrolidone, $7 \mathrm{mg} / \mathrm{ml}$ bovine serum albumin, $0.15 \mathrm{mg} / \mathrm{ml}$ yeast transfer RNA, $0.33 \mathrm{mg} / \mathrm{ml}$ denatured herring salmon sperm DNA, and 20 $\mathrm{mm}$ dithiothreitol (DTT). From this prehybridization incubation, the sections were transferred into fresh hybridization buffer containing cRNA probes at a density of $10^{6} \mathrm{cpm} / 100 \mu \mathrm{l}$ with an addition of $20 \mathrm{mM}$ DTT and incubated overnight at $60^{\circ} \mathrm{C}$. After hybridization, sections were transferred through $4 \times \operatorname{SSC}(1 \mathrm{hr})$ and ribonuclease $\mathrm{A}(20 \mu \mathrm{g} / \mathrm{ml})$ at $45^{\circ} \mathrm{C}$ for
$30 \mathrm{~min}$, and washed through descending concentrations of SSC to a final stringency of $0.1 \times$ SSC for $1 \mathrm{hr}$. Sections were mounted onto vectabond (Vector Laboratories, Burlingame, CA) coated slides, air dried, and exposed to film ( $\beta$-max, Amersham).

The rat bFGF cRNA probes for in situ hybridization were synthesized from a 1004 bp cDNA fragment subcloned into the XhoI site of pBluescript SK+ (Shimasaki et al., 1988). The antisensc RNA probes were transcribed from the $P v u I I$-linearized plasmid using T7 RNA polymerase in presence of $\left[{ }^{35} S\right]$ uridine triphosphate $\left(\left[{ }^{35} \mathrm{~S}\right] \mathrm{UTP}\right)$. As control for specificity of hybridization of the $\mathrm{bFGF}$ cRNA probe, sections from experimental and control rats were processed in parallel with a ${ }^{35} \mathrm{~S}$-labeled bFGF sense cRNA probe. The sense RNA probes were transcribed using T3 RNA polymerase in presence of $\left[{ }^{35}\right.$ S]UTP. The rat NGF cRNA probes (750 bases) were transcribed in the presence of $\left[{ }^{35} \mathrm{~S}\right] \mathrm{UTP}$ from a PvuII-linearized genomic subclone pBSrNGF (Whittemore et al., 1988) using T3 RNA polymerase.

Quantitation of in situ hybridization. Optical density (OD) values of silver grains resulting from hybridization were measured from film autoradiograms. NGF and bFGF mRNA hybridization signal obtained on the autoradiographic film was quantitated using National Institutes of Health computer-assisted image analysis program (National Institutes of Health version 1.56). Optical densities were calibrated relative to densitics obtained from slide-mounted $\left[{ }^{14} \mathrm{C}\right]$ Microscales standards (Amershim) exposed for the same amount of time. Measurements were taken from the dorsal and the ventral leaf of dentate gyrus stratum granulosum, and the layers of CA1, CA2, piriform cortex, and cingulate cortex defined by the hybridization signal. Stratum lacunosum moleculare and cortical mealsurements were taken over a defined area of cach structure and were kept identical across the different sections sampled. Sampled areas were magnificd to allow 10 pixel measurements. Because three different sections per animal $(\mathrm{n}=2)$ were analyzed, 60 measurements per anatomical structure were computed. Background measurements were obtained from an unhybridized area within the tissue section and a neighboring film area. The data from DEX-treated animals are cxpressed relative to hybridization OD from control rats proccssed side by side and exposed on the same piece of film.

Detection of bFGF by Western blot analysis. Brain tissue extracts from frozen samples were prepared by homogenization in $10 \mathrm{vol}(\mathrm{w} / \mathrm{v})$ of ice cold NP-40 buffer [10 mM Tris buffer, pH 7.4, 1 mm EDTA (TE), $1 \%$ NP-40, $2 \mathrm{M} \mathrm{NaCl}, 1 \mathrm{~mm}$ phenylmethylsulphonyl fluoride, $1 \mu \mathrm{g} / \mathrm{ml}$ aprotinin, $1 \mu \mathrm{g} / \mathrm{ml}$ leupeptin, (Sigma)] with 10 strokes by hand in a $2 \mathrm{ml}$ teflon glass homogenizer. Samples were centrifuged for $20 \mathrm{~min}$ at $15,000 \times \mathrm{g}$. Protein concentration in the supernatant was measured by Coomassieblue assay (Bio-Rad, Melville, NY). The supernatant was collected and the $\mathrm{NaCl}$ concentration was adjusted to $0.6 \mathrm{M}$ with TE containing protease inhibitors. Fractions of the supernatant $(400 \mu \mathrm{l})$ were added to a tube containing $50 \mu \mathrm{l}$ of heparin-Sepharose CL-6B slurry (Pharmacia, Piscataway, NJ) $(100 \mathrm{mg}$ swelled in $1 \mathrm{ml}$ of TE containing $0.6 \mathrm{M} \mathrm{NaCl})$ and shaken overnight at $4^{\circ} \mathrm{C}$. The heparin-Sepharose was precipitated at $13,000 \times g$, and the pellet was washed three times with $0.6 \mathrm{M} \mathrm{NaCl}, 10 \mathrm{~mm}$ Tris $\mathrm{HCl}, \mathrm{pH} 7.4$. Final pellets were boiled in loading buffer ( $2 \%$ SDS, 100 $\mu \mathrm{M}$ DTT, $10 \%$ glycerol, $0.25 \%$ bromophenol blue) and separated by a $15 \%$ SDS-polyacrylamide gel. Recovery of bFGF was monitored by including tracer amounts $(10,000 \mathrm{cpm})$ of ${ }^{125} \mathrm{I}-\mathrm{bFGF}(50 \mu \mathrm{Ci} / \mu \mathrm{g}, \mathrm{ICN}$ Research Products, Costa Mesa, CA). Recovery ranged from $75-85 \%$. Protein was transferred in $10 \mathrm{mM}$ Tris/glycine/methanol buffer for $1 \mathrm{hr}$ onto nitrocellulose filter. Prestained molecular weight markers (Life Technologies, Gaithersburg, MD), human recombinant bFGF (a gift from Farmitalia-Carlo Erba, s.p.a., Milan, Italy), and aFGF (Collaborative Research, Bedford, MA) were run simultaneously. Immunostaining of blotted proteins was performed using the mouse bFGF monoclonal antibody DE6 (Reilly et al., 1989) (a gift from Dr. W. Herblin, Dupont Merck Pharmaccutical Company, Wilmington, DE) at a dilution of $1 / 500$. Blots were analyzed using enhanced chemiluminescence (Amcrsham).

\section{RESULTS}

\section{DEX increases bFGF and NGF mRNA levels in the cerebral cortex and hippocampus}

We have previously shown that physiologically low levels of adrenal corticosteroids, such as those obtained by bilateral adrenalectomy, result in reduced levels of NGF and bFGF mRNA in the cerebral cortex (Follesa and Mocchetti, 1993; Follesa et al., 1994). To examine the role of blood-borne adrenal steroids in the reg- 
A

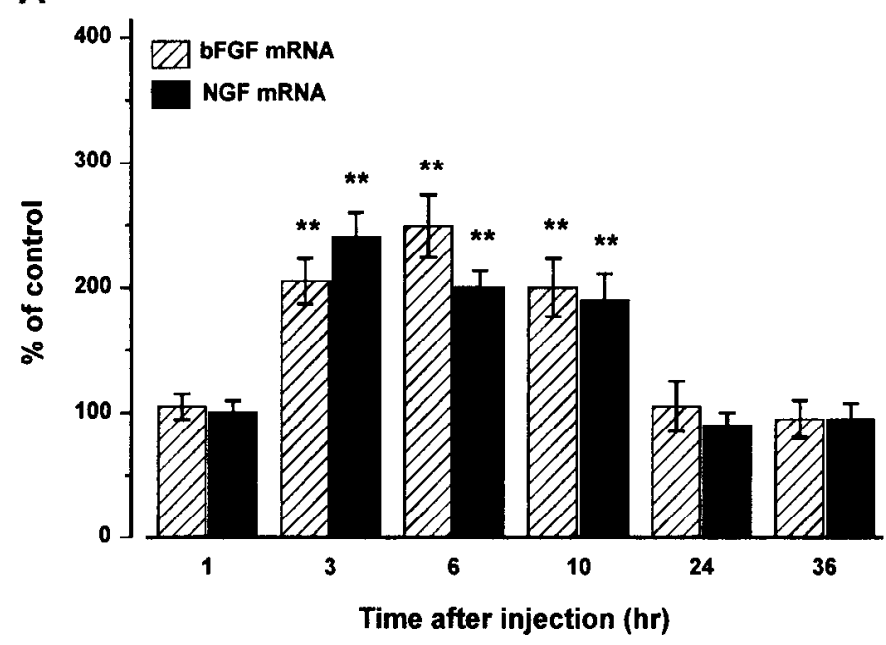

B

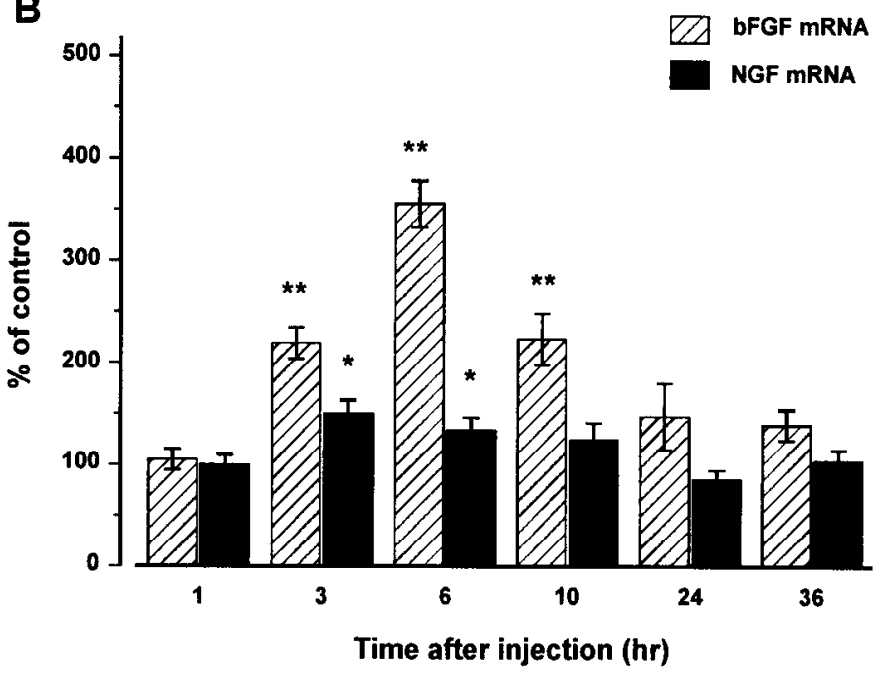

Figure 1. DEX induces a time-dependent increase in NGF and bFGF mRNA in the cerebral cortex and hippocampus. Rats received DEX (0.5 mg/kg, s.c.) and were killed at the indicated time. The content of $b F G F$ and $N G F m R N A$ was determined in cerebral cortex $(A)$ and hippocampus $(B)$ by RNase protection assay. Data, expressed in percent of control, are the mean \pm SEM of three separate experiments $(n=9 /$ group $) .{ }^{*} p<0.05,{ }^{* *} p<0 .(0)$ versus control (ANOVA and Dunnett's test).

ulation of trophic factor expression in the brain, rats were injected with the synthetic glucocorticoid DEX. Time-course studies revealed that in the cerebral cortex, $\operatorname{DEX}(0.5 \mathrm{mg} / \mathrm{kg}$, s.c. $)$ failed to change the levels of both mRNAs at $1 \mathrm{hr}$, but elicited a twofold increase in bFGF and NGF mRNA content $3 \mathrm{hr}$ after the injection (Fig. 1A). The profile of bFGF mRNA induction was slightly different from that of NGF because accumulation of bFGF mRNA reached peak values at $6 \mathrm{hr}$ (Fig. $1 A$ ), whereas NGF mRNA levels started to decline by $6 \mathrm{hr}$. The content of both mRNA species gradually returned to control levels within $24 \mathrm{hr}$ postadministration of DEX. In contrast, NGF and bFGF mRNA levels remained constant over time within the control groups, fluctuating no more than $10 \%$. Moreover, the content of aFGF mRNA remained unchanged over time in the DEX-treated cohort (data not shown), indicating specificity in the induction of bFGF IIRNA.

Time-course studies were also performed to characterize the temporal pattern of NGF and bFGF mRNA in the hippocampus after systemic DEX administration. By $3 \mathrm{hr}$, DEX elicited a significant increase in bFGF and NGF mRNA (Fig. 1B). By 6 hr, however, the content of NGF mRNA started to decline, whereas that of bFGF reached peak induction (Fig. $1 B$ ). bFGF mRNA remained elevated at $10 \mathrm{hr}$ (twofold) and returned to control values by $36 \mathrm{hr}$ (Fig. $1 B$ ).

\section{Dose-response studies}

The dose of DEX $(0.5 \mathrm{mg} / \mathrm{kg}$, s.c. $)$ used to increase the content of NGF and bFGF mRNA roughly approximates plasma glucocorticoid levels occurring during intense stress (Sapolsky et al., 1986). Dose-response studies were performed to determine whether lower or higher concentrations of DEX can elicit a comparable accumulation of trophic factor mRNA. In the cerebral cortex, by $3 \mathrm{hr}$ the dose of $0.1 \mathrm{mg} / \mathrm{kg}$ (s.c.) elicited a modest but significant increase in the levels of both mRNAs (Fig. 2). The peak effect was observed at a dose of $5 \mathrm{mg} / \mathrm{kg}$ (s.c.). The levels of bFGF and NGF mRNA failed to significantly differ at doses of $0.5,1$, and $5 \mathrm{mg} / \mathrm{kg}$ (Fig. 2). A similar concentration-dependent increase in both mRNAs was observed in the hippocampus (data not shown).

\section{Anatomical specificity of bFGF and NGF mRNA induction after DEX}

We examined the lcvels of NGF and bFGF mRNA in additional brain regions at various times after DEX $(0.5 \mathrm{mg} / \mathrm{kg})$. The synthetic glucocorticoid elicited a time-dependent increase in bFGF mRNA in the hypothalamus, cerebellum, and striatum similar to that observed in the cerebral cortex. Thus, the DEX-induced increase in bFGF mRNA peaked at $6 \mathrm{hr}$ (Fig. 3) and declined by 24 hr (data not shown). In these brain regions, NGF mRNA failed to change at any time (data not shown) consistent with previous findings (Fabrazzo et al., 1991).

We used in situ hybridization to localize NGF and bFGF mRNA induction in specific areas of the brain in which we may have failed to detect changes because of induction restricted to a particular

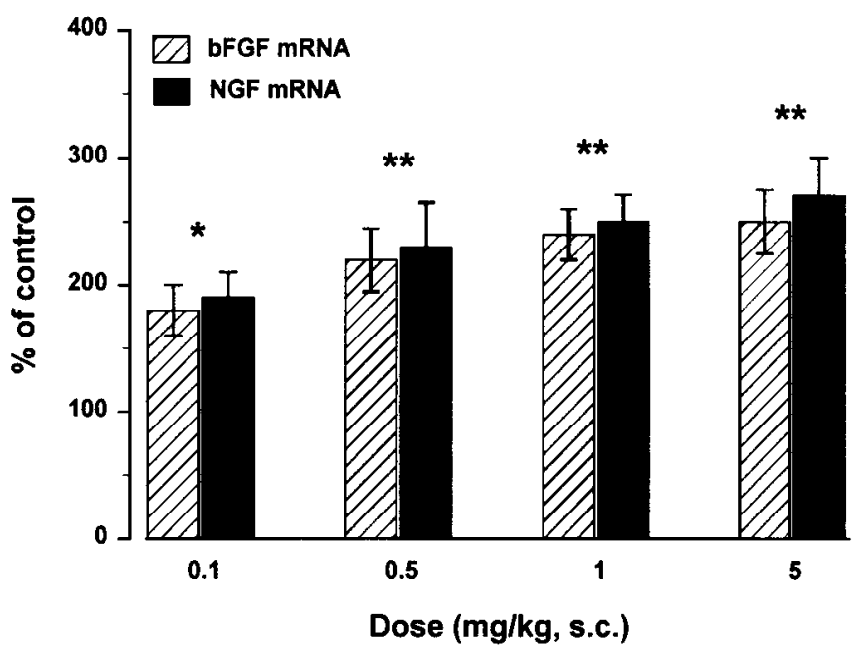

Figure 2. Induction of NGF and bFGF mRNA by DEX: dose-response studies. DEX was injected subcutaneously at the indicated doses, and rats were killed $3 \mathrm{hr}$ later. Values are expressed as percent of control and are the mean \pm SEM of two independent and separate experiments $(n=4 /$ group). ${ }^{*} p<0.05,{ }^{* *} p<0.01$ versus control (ANOVA and Dunnett's test). 


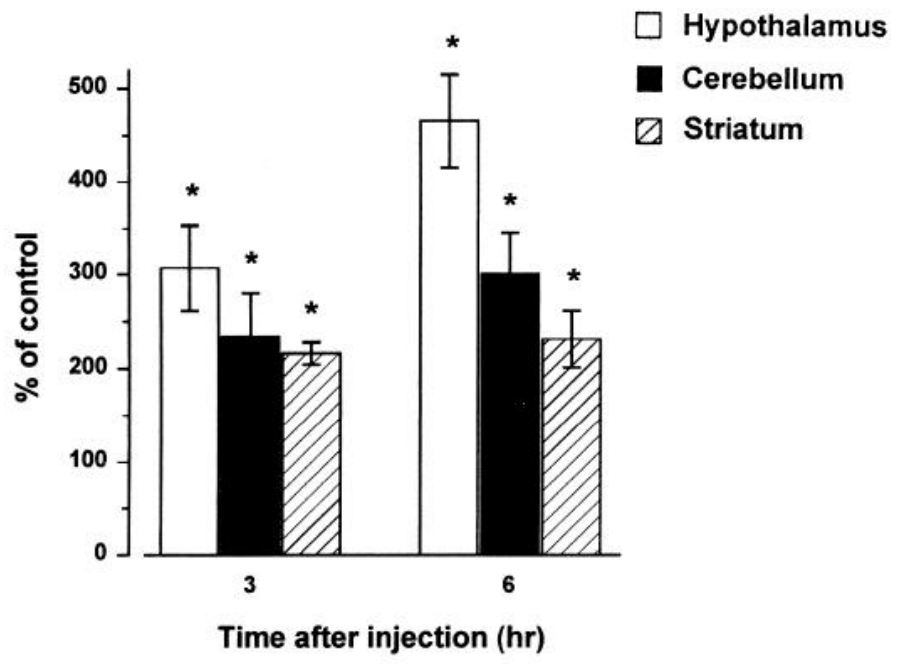

Figure 3. Regional increase in bFGF mRNA after DEX. Rats received DEX $(0.5 \mathrm{mg} / \mathrm{kg}$, s.c. $)$ and were killed at the indicated time. Hypothala$m u s$, cerebellum, and striatum were dissected. Data are the mean \pm SEM of three separate experiments $\left(n=9 /\right.$ group). ${ }^{*} p<0.01$ (ANOVA and Dunnett's test). No changes were observed in the levels of NGF mRNA between control and DEX-treated rats in these areas.

subset of cell layers. In control rats, NGF mRNA was relatively abundant in hippocampus dentate gyrus and in the superficial layers of the cortex (Fig. 4), similar to previous observations (Gall and Isackson, 1989; Gall et al., 1991; Isackson et al., 1991; Hayes et al., 1995). In brain sections of rats killed $3 \mathrm{hr}$ after DEX injection, antisense NGF cRNA probe hybridization revealed that NGF mRNA levels were increased in the superficial layers of the cortex and in particular in the cingulate and piriform cortex (Fig. 4 and Table 1), supporting the data obtained with RNase protection assay. In the hippocampus, NGF mRNA levels remained unchanged in the pyramidal cell layers, but increased in the dentate granule cell layers of the same brains (Fig. 4 and Table 1).

Brain sections of control rats, processed with bFGF cRNA, showed the typical bFGF hybridization scattered throughout the brain, as shown previously (Emoto et al., 1989; Gall et al., 1994; Hayes et al., 1995), which suggests expression of bFGF in glial cells. bFGF hybridization was also localized in the CA2 layer of the hippocampus, where bFGF mRNA has been found to be expressed in neurons (Woodward et al., 1992). DEX-treated rats showed elevated levels of bFGF mRNA expression evenly distributed over all cortical regions (Fig. 4). In the hippocampus, DEX increased bFGF mRNA expression in glial cells within the stratum

Table 1. Effect of DEX on NGF and bFGF mRNAs: analysis by in situ hybridization

\begin{tabular}{|c|c|c|c|}
\hline \multicolumn{2}{|l|}{ NGF mRNA } & \multicolumn{2}{|c|}{ bFGF mRNA } \\
\hline Brain areas & $\%$ of control & Brain areas & $\%$ of control \\
\hline CG & $360 \pm 80^{*}$ & CA1 & $142 \pm 18^{*}$ \\
\hline DG & $317 \pm 67^{*}$ & $\mathrm{CA} 2$ & $81 \pm 14$ \\
\hline \multirow[t]{2}{*}{ PIR } & $302 \pm 70^{*}$ & CTX & $178 \pm 47^{*}$ \\
\hline & & SLM & $218 \pm 81^{*}$ \\
\hline
\end{tabular}

Data are the mean \pm SEM values. Results are relative to the paired control and averaged from three different sections from two individual animals. CTX, Cortex; CG, cingulate gyrus; DG, dentate gyrus; PIR, piriform cortex; SLM, stratum lacunosum moleculare.

${ }^{*} p<0.05$ (Student's $t$ test).
Cont.

Dex.

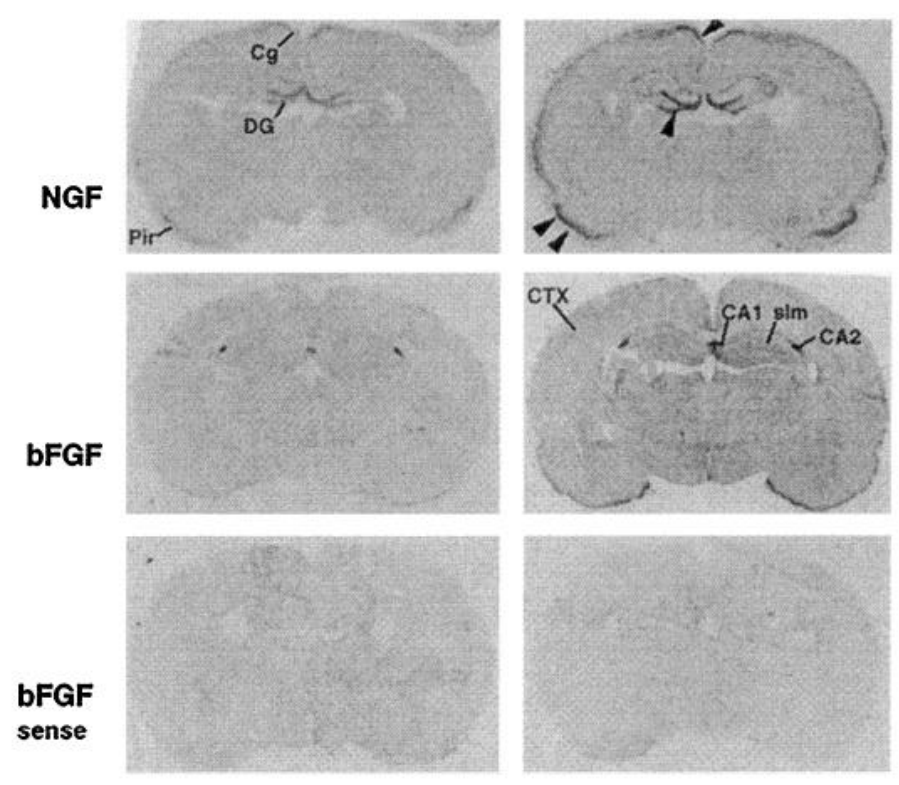

Figure 4. Effect of DEX on NGF and bFGF mRNA expression. Photomicrographs of autoradiograms of in situ hybridization showing the expression of NGF and bFGF mRNAs in the brain of control (Cont.) versus DEX-treated rats (Dex.). Coronal sections of the rostral areas of the rat brain are shown. CTX, Cortex; $\mathrm{Cg}$, cingulate gyrus; Pir, piriform cortex; $D G$, dentate gyrus; slm, stratum lacunosum moleculare. Arrowheads indicate areas of significant NGF mRNA increase.

lacunosum moleculare (Fig. 4). In the CA2 region, we failed to observe increased hybridization after DEX (Table 1). Tissue processed with the sense bFGF cRNA probe showed no labeling in any of the regions where specific bFGF hybridization was described above (Fig. 4), confirming the specificity of the signal obtained with antisense bFGF cRNA probe.

\section{Induction of bFGF protein after DEX}

DEX has been shown to increase NGF protein in rat cerebral cortex (Fabrazzo et al., 1991) and in the hippocampus (Saporito et al., 1994). To determine whether DEX increases bFGF protein, hippocampal extracts of control and experimental animals were analyzed by Western blot using DE6, a bFGF monoclonal antibody that does not show cross reactivity with aFGF (Reilly et al., 1989) (Fig. 5A, lane 5). DE6 recognizes two characteristic forms of the recombinant human bFGF; a dominant fragment of $\sim 18 \mathrm{kDa}$, and a higher molecular weight $(\sim 36 \mathrm{kDa})$ immunoreactive bFGF form (Fig. 5A, lanes $2-4$ ), which may represent the nonreducible dimer. In tissue extracts (heparin-bound material), DE6 recognizes, in addition to the $18 \mathrm{kDa}$ band (light arrow), two higher molecular forms of bFGF (22-24 kDa) (Fig. 5B, arrowhead), most likely originating from a $5^{\prime} \mathrm{CUG}$ codons as demonstrated by other investigators (Florkiewicz and Sommer, 1989; Woodward et al., 1992). In addition, the antibody recognizes some higher molecular weight forms, which might represent the nonreducible dimer and related proteolytic fragments. Although the biochemical nature of these putative high molecular weight forms is still under investigation, they are likely to be derivatives of bFGF, because an aFGF antibody failed to immunoprecipitate these fragments (Koshinaga et al., 1993).

Analysis of tissue extracts from hippocampus of rats treated with vehicle or DEX and killed at different times revealed that 
A

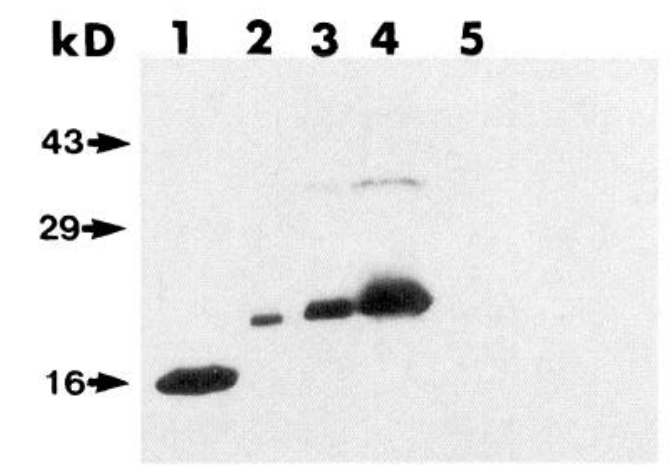

B

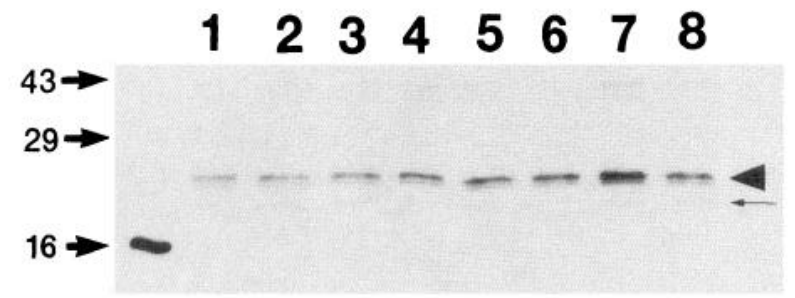

Figure 5. DEX increases bFGF protein: Western blot analysis. Hippocampi were dissected from control and DEX-treated rats $6 \mathrm{hr}$ after the injection. Heparin-binding proteins were enriched by affinity chromatography (see Materials and Methods) and analyzed by Western blot using DE6 antibody (dilution 1:500). A, Lane 1: Molecular weight marker; lanes 2-4: human recombinant $\mathrm{bFGF}(1,5$, and $10 \mathrm{ng}$, respectively); lane 5 : aFGF (10 ng). $B$, Representative blot analyzing hippocampal extracts ( $1 / 7$ of the total extract) from four separate control rats (lanes 1-4) and DEX-treated rats (lanes 5-8). Arrowhead indicates the 22-24 kDa bFGF forms, light arrow the $18 \mathrm{kDa}$ form. The experiment was repeated twice with comparable results.

DEX failed to change bFGF proteins by $3 \mathrm{hr}$ (data not shown). By $6 \mathrm{hr}$, the glucocorticoid elicited a twofold increase $(190 \% \pm 20)$ in the two major ( 22 and $24 \mathrm{kDa}$ ) bFGF immunoreactive species (Fig. 5B, lanes 5-8). The content of bFGF proteins decreased almost to control values by $24 \mathrm{hr}$ (data not shown).

\section{Induction of NGF and bFGF mRNA by ACTH}

ACTH regulates the synthesis and release of adrenal corticosteroids (Axelrod and Reisine, 1984). We examined whether ACTH could evoke an induction in NGF and bFGF mRNA similar to that elicited by DEX. The administration of ACTH $(15 \mathrm{U} / \mathrm{Kg}$, s.c.) increased both mRNA levels in the cerebral cortex (Fig. 6A) and hippocampus (Fig. 6B). To further test the role of ACTH and adrenal corticosteroids in the regulation of bFGF and NGF mRNA expression, ACTH or DEX was injected in adrenalectomized rats. In these animals, ACTH failed to change NGF and bFGF mRNA levels in both regions (Fig. $6 A, B$ ). However, adrenalectomy did not prevent the DEX-mediated accumulation of NGF and bFGF mRNA in both the cerebral cortex and hippocampus (Fig. $6 A, B$ ), supporting the important role of adrenal corticosteroids in the ACTH-mediated regulation of NGF and bFGF expression.

\section{Aldosterone and corticosterone change NGF and bFGF mRNAs}

We next used corticosterone (CORT) and aldosterone (ALDO) to examine the role of blood-borne steroids in the induction of
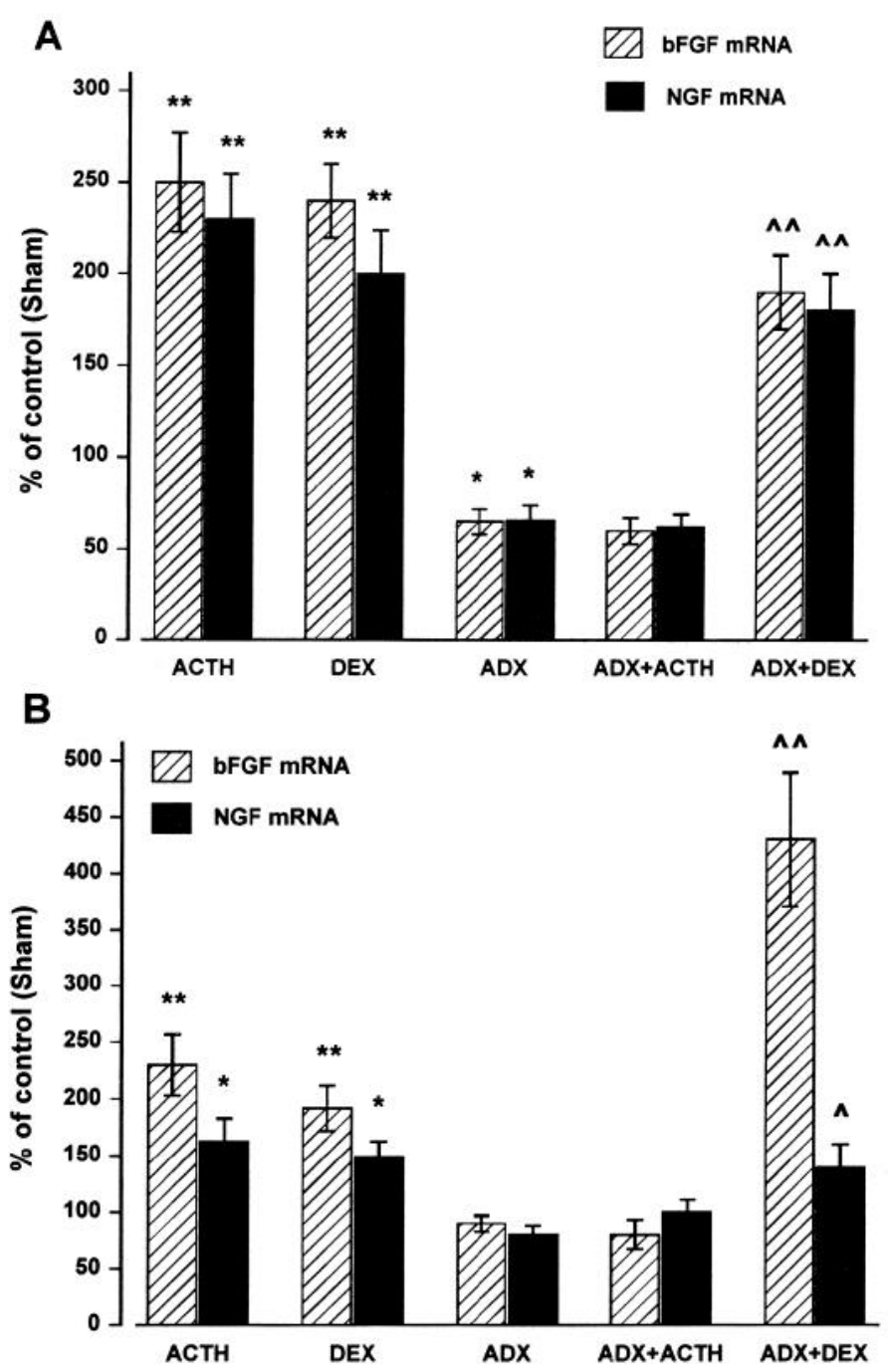

Figure 6. ACTH induces $\mathrm{bFGF}$ and NGF $\mathrm{mRNA}$ in rat cerebral cortex and hippocampus. Sham and adrenalectomized $(A D X)$ rats received a subcutaneous injection of vehicle, $A C T H(15 \mathrm{U} / \mathrm{kg})$, or $D E X(0.5 \mathrm{mg} / \mathrm{kg})$ and were killed $5 \mathrm{hr}$ later. $b F G F$ and $N G F m R N A$ levels were measured in the cerebral cortex $(A)$ and hippocampus $(B)$. Data, expressed as percent of control (sham), are the mean \pm SEM of three separate experiments ( $n$ $=6$ /group). ${ }^{*} p<0.05$ versus sham; ${ }^{* *} p<0.01$ versus sham; $\wedge p<0.05$ versus $\mathrm{ADX} ; \hat{\wedge} \wedge<0.01$ versus ADX (ANOVA and Dunnett's test).

NGF and bFGF mRNA expression. By $3 \mathrm{hr}$, both CORT (10 $\mathrm{mg} / \mathrm{kg}$, s.c.) and ALDO (10 mg/kg, s.c.) increased the content of bFGF mRNA in the cerebral cortex to a similar extent (Fig. 7A). However, the CORT-mediated increase in NGF mRNA levels was significantly different from that evoked by ALDO (Fig. 7A). Dose-response studies revealed that both steroids failed to change NGF and bFGF mRNA at a dose of $1 \mathrm{mg} / \mathrm{kg}$ (s.c.). At a dose of $5 \mathrm{mg} / \mathrm{kg}$ (s.c.), CORT, but not ALDO, increased bFGF and NGF mRNA $\sim 1.5$-fold (data not shown).

In the hippocampus, the CORT-evoked changes in the expression of both NGF and bFGF mRNA followed a pattern similar to that observed after DEX. Thus, by $3 \mathrm{hr}$, the natural glucocorticoid elicited a 3 - and 1.5-fold increase in bFGF and NGF mRNA, respectively (Fig. $7 B$ ). In contrast, ALDO failed to change NGF mRNA levels, and induced bFGF mRNA to an extent weaker than that observed after CORT (Fig. 7B). 


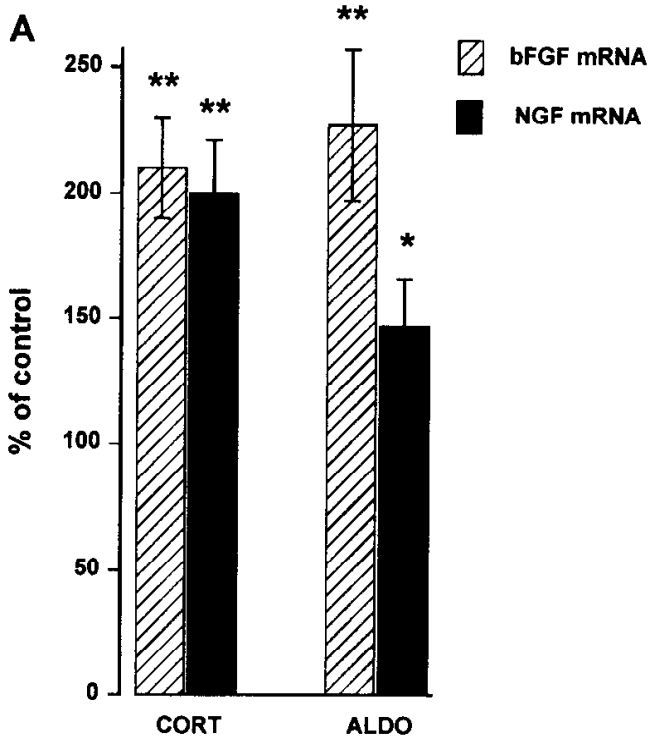

B

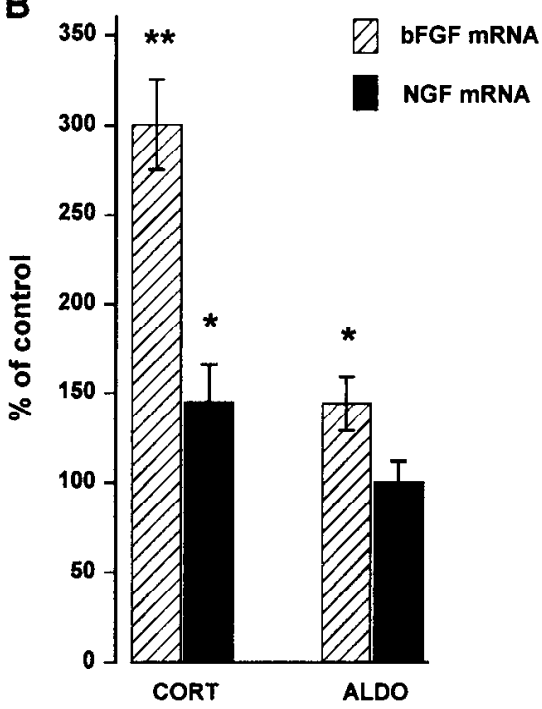

Figure 7. Effect of corticosterone and aldosterone on NGF and bFGF mRNA in the cerebral cortex and hippocampus. Rats were injected with CORT $(10 \mathrm{mg} / \mathrm{kg}, \mathrm{s.c}$ ) or $A L D O(10 \mathrm{mg} / \mathrm{kg}$, s.c.) and killed $3 \mathrm{hr}$ later. Cerebral cortex $(A)$ and hippocampus $(B)$ were dissected, and $N G F$ and $b F G F m R N A$ levels were determined simultaneously by RNase protection assay. Data are the mean \pm SEM of two independent and separate experiments $\left(n=3\right.$ /group). ${ }^{*} p<0.05,{ }^{*} p<0.01$ (ANOVA and Dunnett's test).

\section{DISCUSSION}

In addition to playing an important role in mediating stress responses, adrenal corticosteroids influence survival of specific neuronal populations (Sloviter et al., 1989; Gould et al., 1990). We have used $\mathrm{ACTH}$, naturally occurring adrenal steroids, and the synthetic glucocorticoid DEX to test the importance of these hormones in the induction of neurotrophic factor expression in rat brain. The data presented here demonstrate that ACTH, CORT, ALDO, and DEX increase brain levels of the mRNA for NGF and $\mathrm{bFGF}$, two polypeptides that exert trophic activity on basal forebrain cholinergic neurons (for review, see Mocchetti and Wrathall, 1995), suggesting that the adrenal cortical system may influence neuronal plasticity.

The DEX-induced accumulation of NGF mRNA is temporally and anatomically distinct from that of bFGF mRNA. Whereas NGF mRNA induction peaks at $3 \mathrm{hr}$, that of bFGF peaks at $6 \mathrm{hr}$ in most of the brain regions examined. Moreover, the DEXmediated induction of NGF mRNA is confined to the cerebral cortex and hippocampus, whereas bFGF mRNA increase occurs in several brain areas, suggesting that transcriptional activation and DNA-binding properties of NGF and bFGF promoters may respond differently to changes in hormone levels. Indeed, the results obtained by in situ hybridization show that the DEXmediated increase in NGF mRNA levels is localized in superficial layers of the cerebral cortex and in the dentate gyrus of the hippocampus, indicative of enhanced neuronal expression. Instead, the DEX-evoked accumulation of bFGF mRNA levels was localized in glial cells of the hippocampal stratum lacunosum moleculare, but not in laycrs of the hippocampus enriched in neurons such as CA1 and CA2. Furthermore, in the cerebral cortex, the glucocorticoid-mediated induction of bFGF $m$ RNA is widespread and heterogeneous, consistent with the suggestion that bFGF expression is induced in glial cells. Thus, our data are in line with the notion that pharmacologically induced expression of the NGF gene in adult uninjured rat brain occurs primarily in neurons (Isackson et al., 1991; Hayes et al., 1995) and further support the suggestion that glial cells are able to express bFGF mRNA in response to noninjurious changes in synaptic activity (Hayes et al., 1995).

It has been established that DEX increases NGF protein in the cerebral cortex of developing and adult rats (Fabrazzo et al., 1991; Saporito et al., 1994). The data presented here show that in the hippocampus, DEX also increases bFGF protein. The accumulation of bFGF protein temporally follows the increase in bFGF mRN $\Lambda$. In fact, a significant increase in bFGF protein levels was observed at $6 \mathrm{hr}$. A similar "delay" in protein induction after DEX has been observed for NGF in the cerebral cortex (Fabrazzo et al., 1991), suggesting that accumulation of neurotrophic factor proteins is an event secondary to the activation of bFGF (or NGF) gene transcription or mRNA stabilization. Although a complete time-course study on the effect of DEX on bFGF protein has not been carried oul, overall, our data indicate that stimulation of glucocorticoid receptors enhances the synthesis and availability of these trophic factors in selected regions of the adult rat CNS.

The exact mechanism by which adrenal steroids stimulate bFGF and NGF mRNA accumulation does not appear to be easily definable. Brain corticosteroid receptors are pharmacologically and anatomically distinct. Type I receptors have high affinity for both mineralcorticoids and glucocorticoids, and a three- to fivefold lower affinity for the synthetic glucocorticoid DEX (Beaumont and Fanestil, 1983; Reul and DeKloct, 1985). In contrast, type II receptors possess high affinity for DEX and a 10- to 20-fold lower affinity for ALDO (DeKloet et al., 1975; Krozowski and Funder 1983; Spencer et al., 1990). Thus, DEX has been considered a type II receptor agonist. Moreover, regional studies on the density of these receptors have shown a contrasting variability, with type I being far more abundant in the hippocampus, and type II uniformly expressed throughout the brain (Fuxe et al., 1985; Reul and DeKloet, 1985; Chao et al., 1989). In this study, we have provided several lines of evidence which demonstrate that glucocorticoids, and not mineralcorticoids, are the main corticosteroids regulating the expression of NGF and bFGF mRNA. First, the DEX-mediated increase in NGF and bFGF mRNA occurs in different brain areas, in accordance with the wider distribution of type II receptors. Second, CORT, but not ALDO, elicits an anatomical increase in NGF and bFGF mRNA expression similar 
in magnitude to that observed after DEX. Finally, in the hippocampus, an area rich in type I receptors, ALDO minimally increased bFGF expression and failed to change the expression of NGF mRNA. Thus, although we cannot definitively rule out a role for mineralcorticoids, it appears that expression of NGF and bFGF is predominantly under the control of glucocorticoids. Whether these neurotrophic factors are colocalized with cells expressing type II receptors is still unclear. Isotopic and colorimetric labeling will allow us to determine whether bFGF and NGF mRNA colocalize with type II receptors and whether the selective anatomical activation of these trophic factors is attributable to a direct control of glucocorticoids or to a transsynaptic mechanism evoked by DEX.

The dose of DEX used for these studies roughly mimics the concentration of blood corticosterone after excessive stress (Sapolsky et al., 1986). Stress has been shown to affect expression of neurotrophins in the hippocampus (Smith et al., 1995), indicating that the pituitary-adrenocortical axis is involved in the regulation of neurotrophic factor synthesis. Seizure-evoked stress can cause the relcase of ACTH and the conscquent rise in blood glucocorticoid concentration. On the other hand, seizure-evoked synaptic activity has been shown to increase the expression of NGF and bFGF in the hippocampus and cerebral cortex (Gall and Isackson, 1989; Riva et al., 1992; Follesa et al., 1994; Gall et al,, 1994), suggesting that trophic factor synthesis may require activation of neurotransmitter receptors. We have previously shown that the seizure-mediated accumulation of hippocampal NGF can be prevented in adrenalectomized rats without compromising the number and duration of seizure episodes (Mocchetti et al., 1991; Sun et al., 1993), indicating that adrenal steroid hormones play an important role in mediating induction of NGF and bFGF mRN $\Lambda$ evoked by seizure episodes. Our findings, by providing direct evidence that $\mathrm{ACTH}$ regulates the expression of bFGF and NGF mRNA in sham-operated but not in adrenalectomized rats, support the suggestion that some of the effects observed after excessive synaptic activity may be attributed to events linked to stress.

The present data, by establishing that ACTH, CORT, and DEX influence accumulation of NGF and bFGF mRNA, confirm the early hypothesis that glucocorticoids may regulate expression of neurotrophic factors in the adult CNS (Mocchetti, 1991), and suggest that hormones may exert their effect on CNS homeostasis via the regulation of trophic factor activity. Thyroxine, for instance, administered to adult mice for $21 \mathrm{~d}$, increases NGF concentration in the cerebral cortex, brainstem, and cerebellum (Walker et al., 1979). Furthermore, in adult mice, intermale aggressive behavior elicited by social isolation for several days induces NGF expression in the magnocellular preoptic and ven trolateral nuclei of the hypothalamus (Spillantini et al., 1989; Aloe et al., 1990), suggesting that NGF may be involved in the regulation of those hypothalamic functions that integrate sexual aggression with sex-rclated endocrine function. Several lines of independent investigations have shown that sex hormones may also play a role in the regulation of neurotrophic factors. Indeed, in the brain, estrogen receptors colocalize with neurotrophin receptors (Miranda et al., 1993). In ovariectomized rats, BDNF mRNA levels decrease in the cerebral cortex (Singh et al., 1995), and estrogen replacement causes a reduction of hippocampal NGF mRNA (Gibbs et al., 1994). Our data have shown that in the hypothalamus DEX increases bFGF mRNA only. Thus, it appears that different classes of hormones may promote expression of different trophic factors in an anatomically specific manner.

Glucocorticoids induce bFGF and NGF biosynthesis. However, the physiological implication of this event remains to be determined. Although it is now unequivocal that bFGF and NGF play an important role during development of the CNS, their potential function in the adult CNS remain controversial. bFGF and NGF have been shown to protect hippocampal and cortical neurons against hypoglycemic damage (Cheng and Mattson, 1991). Glucocorticoids, as in many peripheral tissues, inhibit glucose uptake and utilization in the brain (Sapolsky, 1987), which may limit energy utilization. Neurons are notoriously vulnerable to low energy. Therefore, activation of glucocorticoid receptors, by causing imbalance of glucose availability, may lead to potential neuronal damage. We propose that the increased availability of bFGF and NGF after glucocorticoids may occur as an event in response to potential neuronal damage caused by stress-induced hypoglycemia.

Our data have shown a defined temporal and regional pattern of induction of bFGF and NGF synthesis after DEX and CORT, suggesting that glucocorticoids may possess trophic activity. This hypothesis is supported by the finding that physiological concentration of glucocorticoids is crucial for neuronal survival as adrenalectomy accelerates degeneration of hippocampal neurons (Sloviter et al., 1989). The DEX-mediated induction of trophic factors may enhance neuronal plasticity in uninjured brain. This hypothesis is supported by data (S.J. Rabin and I. Mocchetti, unpublished observations) (Saporito et al., 1994) showing that the DEXmediated increase in NGF appears to exert biological activity as indicated by the induction of phosphorylation of trkA, the highaffinity receptor for NGF. The physiological importance of our findings remains to be established by demonstrating the effects (if any) of acute or prolonged glucocorticoid treatments on neuronal plasticity.

\section{REFERENCES}

Aloe L (1989) Adrenalectomy decreases nerve growth factor in young adult rat hippocampus. Proc Natl Acad Sci 86:5636-5640.

Aloe L, Alleva E, De Simone R (1990) Changes of NGF levels in mouse hypothalamus following intermale aggressive behaviour: biological and immunohistological evidence. Behav Brain Res 39:593-617.

Anderson KJ, Dam D, Lee S, Cotman CW (1988) Basic fibroblast growth factor prevents death of lesioned cholinergic neurons in vivo. Nature $332: 360-361$.

Axelrod J, Reisine TD (1984) Stress hormones: their interaction and regulation. Science 224:452-459.

Barbany G, Persson H (1992) Regulation of neurotrophin mRNA expression in the rat brain by glucocorticoids. Eur J Neurosci 4:396-403.

Beaumont K, Fanestil DD (1983) Characterization of rat brain aldosterone receptors reveals high affinity for corticosterone. Endocrinology 113:2043-2051.

Burgess W, Maciag T (1989) The heparin-binding growth factor family of proteins. Annu Rev Biochem 58:575-590.

Chao HM, Choo PH, McEwen BS (1989) Glucocorticoid and mincralcorticoid receptor mRNA expression in rat brain. Neuroendocrinology 50:365-371.

Cheng B, Mattson MP (1991) NGF and bFGF protect rat hippocampal and human cortical neurons against hypoglycemic damage by stabilizing calcium homeostasis. Neuron 7:1031-1041.

Chomczynski P, Sacchi N (1987) Singlc-step method of RNA isolation by acid guanidinium thiocyanate-phenol-chloroform cxtraction. Anal Biochem 162:156-159.

Colangelo AM, Fink DW, Rabin SJ, Mocchetti I (1994) Induction of nerve growth factor responsiveness in $\mathrm{C} 6-2 \mathrm{~B}$ glioma cells by expression of trkA proto-oncogene. Glia 12:117-127.

DeKloet ER, Wallach G, McEwen BS (1975) Differences in corticosterone and dexamethasone binding to rat brain and pituitary. Endocrinology 96:596-609.

Emoto N, Gonzales A-M, Walicke PA, Wada E, Simmons DM, Shimasaki S, Baird A (1989) Basic fibroblast growth factor in the central nervous 
system: identification of specific loci of basic FGF expression in the rat brain. Growth Factors 2:21-29.

Fabrazzo M, Costa E, Mocchetti I (1991) Reserpine stimulates nerve growth factor biosynthesis in developing rat brain: steroids as possible mediators. Mol Pharmacol 39:144-149.

Florkiewicz RZ, Sommer A (1989) Human basic fibroblast growth factor gene encodes four polypeptides: three initiate translation from nonAUG codons. Proc Natl Acad Sci USA 86:3978-3981.

Follesa P, Mocchetti I (1993) Regulation of basic fibroblast growth factor and nerve growth factor mRNA by $\beta$-adrenergic receptor activation and adrenal steroids in rat CNS. Mol Pharmacol 43:132-138.

Follesa P, Gale K, Mocchetti I (1994) Regional and temporal pattern of expression of nerve growth factor and basic fibroblast growth factor mRNA in rat brain following electroconvulsive shock. Exp Neurol 127:37-44.

Fuxe K, Wikstrom AC, Okret S, Agnati LF, Harfstrand A, Yu ZY, Granholm L, Zoli M, Vale W, Gustafsson JA (1985) Mapping of glucocorticoid receptor immunoreactive neurons in the rat tel-and dienecphalon using a monoclonal antibody against rat liver glucocorticoid receptor. Endocrinology 117:1803-1812.

Gall CM, Isackson PJ (1989) Limbic seizures increase neuronal production of messenger RNA for nerve growth factor. Science 245:758-761.

Gall CM, Murray KD, Isackson PJ (1991) Kainic-acid induced seizures stimulate increased expression of nerve growth factor mRNA in adult rat forebrain. Mol Brain Res 9:113-123.

Gall CM, Berschauer R, Isackson PJ (1994) Scizures increase basic fibroblast growth factor mRNA in adult rat forebrain neurons and glia. Mol Brain Res 21:19()-205.

Gibbs RB, Wu D, Hersh LB, Pfaff DW (1994) Effects of estrogen replacement on the relative levels of choline acetyltransferase, trkA and nerve growth factor messenger RNAs in the basal forebrain and hippocampal formation of adult rats. Exp Neurol 129:70-80.

Glowinski J, Iversen LL (1966) Regional distribution of catecholamines in rat brain. I. The disposition of ${ }^{3} \mathrm{H}$-norepinephrine, dopamine and DOPA in various regions of the brain. J Neurochem 13:655-669.

Goodrich SP, Yan G-CY, Bahrenburg K, Mansson P-E (1989) The nucleotide sequence of rat heparin binding growth factor 1 (HBGF-1). Nucleic Acids Res 17:2867.

Gould E, Woolley CS, McEwen BS (1990) Short term glucocorticoid manipulations affect neuronal morphology and survival in the adult dentate gyrus. Neuroscience 37:367-375.

Harlan RE (1988) Regulation of neuropeptide gene expression by steroid hormones. Mol Neurobiol 2:183-200.

Hayes VY, Isackson PJ, Fabrazzo M, Follesa P, Mocchetti I (1995) Induction of nerve growth factor and basic fibroblast growth factor mRNA following clenbuterol: contrasting anatomical and cellular localization. Exp Ncurol 132:33-41.

Isackson P, Huntsman MM, Murray KD, Gall CM (1991) BDNF mRNA expression is increased in adult rat forebrain after limbic seizures: temporal patterns of induction distinct from NGF. Neuron 6:937-948.

Koshinaga M, Sanon HR, Whittemore SR (1993) Altered acidic and basic fibroblast growth factor expression following spinal cord injury. Exp Neurol 120:32-48.

Krozowski ZS, Funder JW (1983) Renal mineralcorticoids receptor and hippocampal corticosterone-binding species have identical intrinsic steroid specificity. Proc Natl Acad Sci USA 80:6056-6060.

McEwen B, DeKloet ER, Rostene W (1986) Adrenal steroid receptors and action in the nervous system. Physiol Rev 66:1121-1188.

Meyer JS (1985) Biochemical effects of corticosteroids on neuronal tissues. Physiol Rev 65:946-1020.

Miranda RC, Sohrabji F, Toran-Allcrand DC (1993) Presumptive estrogen target neurons express mRNAs for both the neurotrophin receptors: a basis for potential developmental interaction of estrogen with the neurotrophins. Mol Cell Neurosci 4:510-525.

Mocchetti I (1991) Theoretical basis for a pharmacology of nerve growth factor biosynthesis. Ann Rev Pharmacol Toxicol 32:303-328.
Mocchetti I, Wrathall JR (1995) Neurotrophic factors in central nervous system trauma. J Neurotrauma 12:853-870.

Mocchetti I, Sun F-Y, Fabrazzo M, Costa E (1991) Steroid regulation of nerve growth factor biosynthesis in the CNS. In: Neurosteroids and brain function (Costa E, Paul SM, eds), pp 41-46. New York: Thieme.

Otto D, Unsicker K (1990) Basic FGF reverses chemical and morphological deficits in the nigrostriatal system of MPTP-treated mice. J Neurosci 10:1912-1921.

Reilly TM, Taylor DS, Herblin WF, Thoolen MJ, Chiu AT, Watson DW, Timmermans WM (1989) Monoclonal antibodies directed against fibroblast growth factor which inhibit its biological activity in vitro and in vivo. Biochem Biophys Res Commun 164:736-743.

Reul JM, DeKloet ER (1985) Two receptor systems for corticosterone in rat brain: microdistribution and differential occupation. Endocrinology 117:2505-2511

Riva M, Gale K, Mocchetti I (1992) Basic fibroblast growth factor mRNA increases in specific brain regions following convulsive seizures. Mol Brain Res 15:311-318.

Sapolsky RM (1987) Glucocorticoids and hippocampal damage. Trends Neurosci 9:346-349.

Sapolsky RM, Krey LC, McEwen BS (1986) The neurocndocrinology of stress and aging: the glucocorticoid cascade hypothesis. Endocrinol Rev $7: 284-301$.

Saporito MS, Brown ER, Hartpence KC, Heide MW, Robbins E, Vaught J, Carswell S (1994) Systemic dexamethasone administration increases septal trk autophosphorylation in adult rats via an induction of nerve growth lactor. Mol Pharmacol 45:395-401.

Shimasaki S, Emoto N, Koba A, Mercado M, Shibata F, Cooksey K, Baird A, Ling $N$ (1988) Complementary DNA cloning and sequencing of rat ovarian basic FGF and tissue distribution study of its mRNA. Biochem Biophys Res Commun 157:256-263.

Singh M, Meyer EM, Simpkins JW (1995) The effect of ovariectomy and cstradiol replacement on brain-derived neurotrophic factor messenger ribonucleic acid expression in cortical and hippocampal brain regions of female Sprague-Dawley rats. Endocrinology 136:2320-2324.

Sloviter RS, Valiquette G, Abrams GM, Ronk EC, Sollar AL, Paul Lam, Neubort S (1989) Selective loss of hippocampal granule cclls in the mature rat brain after adrenalectomy. Science 243:1432-1437.

Smith MA, Makino S, Kvetnansky R, Post RM (1995) Stress and glucocorticoids affect the expression of brain-derived neurotrophic factor and neurotrophin-3 mRNAs in the hippocampus. J Neurosci 15:1768-1777.

Spencer R, Young E, Choo P, McEwen BS (1990) Glucocorticoid type I and type II receptor binding: estimates of in vivo receptor number, occupancy and activation with varying levels of steroid. Brain Res $514: 37-48$

Spillantini MG, Aloe L, Alleva E, De Simone R, Goedert M, LeviMontalcini R (1989) Nerve growth factor mRNA and protein increase in hypothalamus in a mouse model of aggression. Proc Natl Acad Sci USA 86:8555-8559.

Strand FL, Rose KJ, King JA, Segarra AC, Zuccarelli LA (1989) ACTH modulation of nerve development and regeneration. Prog Neurobiol $33: 45-85$.

Sun F-Y, Costa E, Mocchetti I (1993) Adrenal steroids mediate the increase of hippocampal nerve growth factor biosynthesis following bicuculline convulsions. Neuropsychopharmacology 8:219-225.

Walker CD, Weichsel ME, Fisher DA, Guo SM, Fisher DA (1979) Thyroxine increases nerve growth factor concentration in adult mouse brain. Science 204:427-429.

Whittemore SR, Friedman PL, Larhammar D, Persson H, GonzalesCarvajal M, Holcts VR (1988) Rat $\beta$-nerve growth factor sequence and site of synthesis in the adult hippocampus. J Neurosci Res 20:403-410.

Woodward WR, Nishi R, Meshul CK, Williams TE, Coulombe M, Eckenstein FP (1992) Nuclear and cytoplasmic localization of bFGF in astrocytes and CA2 hippocampal neurons. J Neurosci 12:142-153. 